\title{
IFN $\gamma$-induced PD-L1 expression is JAK2 but not JAK1 dependent and its inhibition enhances NK-cetuximab mediated ADCC of HNSCC cells
}

\author{
Fernando Concha-Benavente ${ }^{1 *}$, Robert L Ferris ${ }^{1,2,3}$ \\ From Society for Immunotherapy of Cancer 29th Annual Meeting \\ National Harbor, MD, USA. 6-9 November 2014
}

Programmed death ligand 1 (PD-L1) is an immunosuppressive molecule expressed by many cancer types, including a large proportion of head and neck cancers (HNC), and ligation of its receptor, programmed death 1 (PD-1), induces exhaustion of effector T cells. It has been shown that interferon gamma (IFN $\gamma$ ) induces PD-L1 expression in many cancer types including glioblastoma, melanoma, lung and kidney cancer. Importantly, the stimuli and mechanism for PD-L1 upregulation in HNC cells are not well characterized. IFN $\gamma$ signals through Janus Kinase 1/2 (JAK1/2) heterodimer complex and mediates signal transducer and activator of transcription 1 (STAT1) phosphorylation, leading to type I cytokine expression, upregulation of antigen presentation, and tumor cell recognition by cytolytic T lymphocytes (CTL). We investigated basal PD-L1 expression and the mechanism by which IFN $\gamma$ signaling upregulates PD-L1 in HNC cells including dependence on JAK/STAT pathway. We observed that IFN $\gamma$ signaling increased PD-L1 expression in a JAK2 but not JAK1 dependent fashion. In addition, interferon alpha (IFN $\alpha$ ), which signals via JAK1/TYK2 did not upregulate PD-L1 expression while still upregulated HLA class I. Specific JAK2 inhibition downregulated NK cell-derived IFN $\gamma$ induced PD-L1 expression and enhanced cetuximab mediated ADCC. Our data suggest a crucial role for JAK2/STAT1 in IFN $\gamma$ mediated PD-L1 upregulation. JAK2 inhibition provides a promising strategy to increase tumor cell lysis through maintaining HLA class I while suppressing tumor cell expressed PD-L1 in combination with anti-EGFR cetuximab therapy.

'Department of immunology, Univeristy of Pittsburgh, Pittsburgh, PA, USA Full list of author information is available at the end of the article

\section{Authors' details}

'Department of immunology, Univeristy of Pittsburgh, Pittsburgh, PA, USA. ${ }^{2}$ Department of Otolaryngology, University of Pittsburgh Cancer Institute, Pittsburgh, PA, USA. ${ }^{3}$ Cancer Immunology Program, University of Pittsburgh Cancer Institute, Pittsburgh, PA, USA.

Published: 6 November 2014

doi:10.1186/2051-1426-2-S3-P199

Cite this article as: Concha-Benavente and Ferris: IFN $\gamma$-induced PD-L1 expression is JAK2 but not JAK1 dependent and its inhibition enhances NK-cetuximab mediated ADCC of HNSCC cells. Journal for ImmunoTherapy ofCancer 2014 2(Suppl 3):P199.

Submit your next manuscript to BioMed Central and take full advantage of:

- Convenient online submission

- Thorough peer review

- No space constraints or color figure charges

- Immediate publication on acceptance

- Inclusion in PubMed, CAS, Scopus and Google Scholar

- Research which is freely available for redistribution 